\section{The man who confessed he was a serial killer}

\author{
John Launer
}

In December 1990, two men carried out a bank robbery in a small town in Sweden. It went farcically wrong. The men wore balaclavas and Santa Claus masks, and attempted to fake Finnish accents, but they were well known in the town and were easily recognised. They were arrested immediately. The younger man was sentenced to three and a half years in prison. The other man, a forty-year old called Sture Bergwall, was sent for psychiatric assessment because of a troubled past history. He had been a patient in a secure unit for 5 years in the 1970 s, following sexual harassment of boys. He had also once stabbed someone seriously, was on long-term prescription drugs, and was known to use street drugs as well. Instead of going to prison, he was readmitted to the same secure psychiatric unit he had been in many years previously.

In the normal course of events, Bergwall might have expected to be there for the same period as the prison sentence served by his accomplice. In fact, he remained there for over two decades. A year or two after his admission, he began to disclose to the psychiatric staff that he had at various dates in the past committed murder. In the following years, he confessed to around 39 murders in total, some relating to crimes that had been prominently in the news, while others involved unknown victims. He was convicted of eight of the killings, becoming the most notable serial killer in Swedish history, and a focus of huge media attention. In 2001, he finally announced that he would no longer collaborate in further investigations, so it was impossible to pursue the many other murders he claimed he had carried out.

In the years that followed, an investigative journalist called Hannes Råstam scrutinised the evidence produced at Bergwall's trials. In 2008, he put to Bergwall the proposition that his confessions had been fabricated. He was correct. Bergwall admitted that he had never actually murdered anyone. ${ }^{1}$ As Råstam had deduced, he had built some of his confessions by researching newspaper reports of the original crimes, and had invented others entirely. By 2013, all his

Correspondence to Dr John Launer, Postgraduate Medical Journal, London WC1H 9JP, UK; johnlauner@aol.com

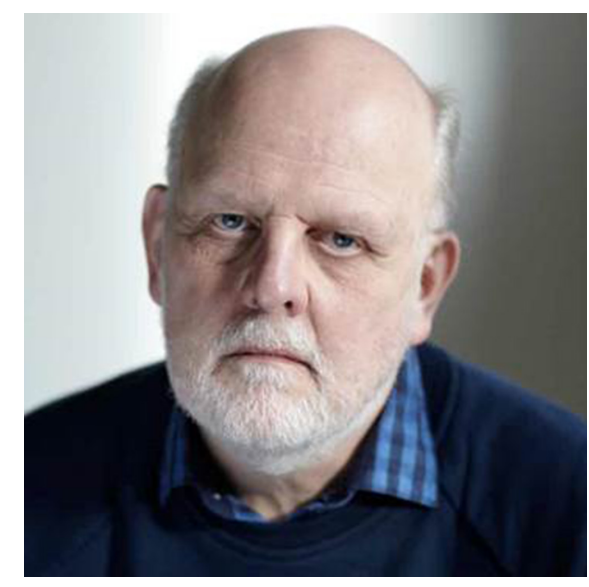

Figure 1 Sture Bergwall. Credit: Andy Hall / Observer / eyevine

convictions had been quashed. He was finally released from the secure unit over two decades after the botched robbery that originally led to his admission, and he remains a free man [see figure 1]. The whole affair - generally known as the Thomas Quick case, after the name that he adopted during the years of his disclosures - shook the Swedish legal, police and psychiatric establishments.

\section{LESSONS FOR ALL}

The case offers lessons that go far beyond the law and psychiatry. It demonstrates how entire groups of professionals, whole institutions and the media, can become fixated on a particular way of seeing the facts, so that they lose all sense of objectivity, even when the evidence to support their view is insubstantial, inconsistent or even absurd. How on earth could this have happened in one of the most developed and admired countries in the world?

For an answer, it is worth looking at the intersecting systems that dealt with Bergwall, beginning with his psychiatric treatment. His medication included antipsychotics and tranquillisers including benzodiazepines. Increasingly, he was allowed almost unlimited amounts on demand, to help him manage what seemed like agonising emotional distress from recalling his past crimes. In addition, he received intensive psychotherapy over the years from three different therapists, with varying levels of experience. One was a doctor with no therapeutic training, and one was a young psychology student who was prone to sharing her own traumatic childhood memories with him. What all the therapists had in common, along with the medical director of the hospital and some other staff, was that they were receiving supervision or therapy, or both, from a charismatic psychoanalyst in Stockholm called Margit Norell. She had once been a member of the Swedish Psychoanalytic Society but had left to form a breakaway institute. After some time that institute also suffered a split and she was expelled, leaving her as the leader of a small but passionate sect of followers, They included most of the clinicians who ended up treating or assessing Bergwall. ${ }^{2}$

Norrell's group shared a belief that much if not all mental illness, including psychosis, resulted from severe abuse in childhood, including sexual and ritual abuse. They also believed that such abuse was later forgotten, but might be compulsively re-enacted in adult life, through carrying out similar acts on others. Through skilful therapy, they argued, such patients could be helped to recover memories of the past and hence gain insight into their dreadful impulses. It is clear that they expected Bergwall to provide convincing proof of their theories.

Bergwall himself, who was not a stupid man, obligingly complied. He described childhood episodes of bloodcurdling awfulness, including being forced to witness his mother's miscarriage and then take part in a cannibalistic ritual with the fetus. His accounts of his murders included horrific details of dismemberment and the ingestion of intimate body parts. He seems to have picked up on every detail in the leading questions his therapists asked, and amplified them in his answers to the point of grotesque parody. This served to meet everyone's needs: fame and vindication for the clinicians, along with attention, drugs and national notoriety for their patient. Significantly, Bergwall only brought his lurid disclosures to an end, refusing to attend therapy any longer, when the medical director finally decided to initiate a strict regime of drug withdrawal.

\section{FLAGRANT CONFABULATIONS}

The police and legal processes that took place during Bergwall's years as Thomas Quick were a remarkably parallel with his psychiatric treatment. The detectives and lawyers involved had a history of poor judgement, and they too wanted their names up in lights. It suited them entirely 
to accept the narrative offered by the clinicians: a textbook example of deeply repressed childhood abuse, its helpless repetition in acts of unspeakable savagery, followed by painfully recovered memories of the abuse and the crimes.

The transcripts of Bergwall's interrogations, along with records of his various trials, reveal how his flagrant, almost jaw-dropping confabulations are continually spurred on by the agents of justice. Time and again, Bergwall gives ludicrously inconsistent accounts of his actions, often at variance with the testimony of other witnesses including his own family members, who think he is making things up. Consistently, police and lawyers discount his 'inaccuracies' as the distortions of the murderer's troubled conscience. as they nudge him towards more accurate memories (for example, the victim's hair was short and brown rather than long and blonde; the meeting was in Stockholm not Uppsala, and so on). Impossibilities are ignored, such as the fact that one murder took place when he was demonstrably hundreds of miles away.

In the hope of finding the scattered heads, hands and other body parts Bergwall claimed to have concealed, his psychiatric and police teams took him on numerous visits to possible crime scenes - travelling to one of these by chartered plane. Bergwall could never do more than stagger around in a drugged stupor and point suggestively to various possible burial sites, before being rewarded with yet more tranquilisers for the distress this appeared to cause him. Massive excavations took place in many of these places, as well as the complete draining of a lake in Norway, all at huge cost. No forensic evidence was ever found. All Bergwall's convictions were made on the basis of his confessions alone. Faced with the absolute clarity and unanimity of all the professionals, and an escalating tally of previous judgements, the courts barely paused for breath before determining his guilt on each occasion. Uncritical newspapers and television reporters revelled in the procedures instead of scrutinising them. A review by the Swedish chancellor of justice concluded in a matter of days that the convictions were watertight. After Bergwall's retraction, the fiasco took several years to unravel. ${ }^{3}$

\section{GROUPTHINK AND INSANITY}

The biggest challenge posed by the story of Bergwall is neither its gruesomeness nor its irresistibly comical side. It is that, in retrospect, it seems utterly obvious that a man who could not even plan a robbery without getting caught could scarcely have murdered several dozen people without leaving one shred of evidence. It is hard to prevent oneself thinking: "I would never have been taken in; my team or hospital would never fall for such fraudulent nonsense; only psychiatrists could be that crazy; I live in a country where we do things differently." Yet Bergwall must have intuitively understood a number of human tendencies that are widespread, including among doctors, and he managed to exploit these brilliantly.

One of these tendencies is that everyone prefers to hear what they want to hear. If our questions do not elicit the answers we expect, we will ask again until the other person works out what to say, in order to please us. Another factor is 'groupthink. ${ }^{4}$ The larger the number of people who believe in an idea, however unfounded and irrational it may be, the harder it becomes for anyone to assess the facts dispassionately, and to see the world in a different way. Perhaps the most important tendency highlighted by the case, however, was that people can find comfort in someone else's insanity. Only too easily, it can serve as a distraction from noticing how readily we can fall prey to it ourselves, both as individuals and collectively.

Funding The authors have not declared a specific grant for this research from any funding agency in the public, commercial or not-for-profit sectors.

Competing interests None declared.

Patient consent for publication Not required.

Provenance and peer review Not commissioned; internally peer reviewed.

(c) Author(s) (or their employer(s)) 2019. No commercial re-use. See rights and permissions. Published by BMJ.

$$
\text { (A) Check for updates }
$$

To cite Launer J. Postgrad Med J 2019;95:293-294.

Received 3 April 2019

Accepted 3 April 2019

Postgrad Med J 2019;95:293-294.

doi:10.1136/postgradmedj-2019-136639

\section{REFERENCES}

1 Råstam H. Thomas Quick: the making of a serial killer. Edinburgh: Canongate, 2013

2 Josefsson D. The strange case of Thomas Quick. The Swedish serial killer and the psychoanalyst who created him. London: Portobello Books, 2015.

3 Heath C. The serial killer has second thoughts: the Confessions of Thomas Quick. Available: https://www. gq.com/story/thomas-quick-serial-killer-august-2013 [Accessed 22 March 2019].

4 Crouch D. Lawyers blame groupthink in Sweden's worst miscarriage of justice. Guardian 5 June 2015. Available: https://www.theguardian.com/world/2015/ jun/05/groupthink-sweden-miscarriage-of-justice-sturebergwall [Accessed 22 March 2019]. 